\title{
Urea Ammonium Nitrate Additive and Raking Improved Mesotrione Efficacy on Creeping Bentgrass
}

\author{
Lijuan Xie ${ }^{1}$, Deying $\mathrm{Li}^{2,4}$, Wenjuan Fang ${ }^{3}$, and Kirk Howatt ${ }^{2}$
}

AdDitional INDEX wORDs. Agrostis stolonifera, postemergent, herbicide, weed, cool-season, turfgrass

SUMMARY. Selective control of creeping bentgrass (Agrostis stolonifera) is desirable when it has escaped into other turfgrasses. The objective of this study was to evaluate the influence on creeping bentgrass control from adding urea ammonium nitrate (UAN) to mesotrione plus non-ionic surfactant (NIS) spray solution, and raking to remove dead tissues of creeping bentgrass. A 2-year field study was conducted with a split-plot design, where raking was the whole plot treatment and herbicide was the sub-plot treatment. Herbicide treatments included application of mesotrione at 56 and $70 \mathrm{~g} \cdot \mathrm{ha}^{-1}$ singly and sequentially with $0.25 \%(\mathrm{v} / \mathrm{v})$ NIS or $0.25 \%(\mathrm{v} / \mathrm{v})$ NIS plus $2.5 \%(\mathrm{v} / \mathrm{v})$ UAN solution. Sequential applications were made three times on a 2 -week interval. Removing the dead clippings by raking improved the creeping bentgrass control from $60 \%$ to $73 \%$ averaged over rates, timings, adjuvants, and years. Adding UAN to NIS plus mesotrione improved creeping bentgrass control from $78 \%$ to $98 \%$ with three sequential applications at $70 \mathrm{~g} \cdot \mathrm{ha}^{-1}$.

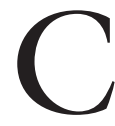
reeping bentgrass is used widely on golf-putting greens and fairways in temperate regions. The strong tolerance to close mowing and low temperatures makes creeping bentgrass very competitive in its adapted region compared with other species (Adams, 1981). However, creeping bentgrass becomes a weed when escaped into other turfgrasses because it reduces uniformity due to differences in textures and growth habit (Turgeon, 1981). Selective removal of creeping bentgrass may be necessary in such circumstances. Bhowmik and Drohen (2001) reported selective control of creeping bentgrass using isoxaflutole (Balance ${ }^{\circledR}$ Flexx; Bayer CropScience, Research Triangle Park, NC), with minor injury to other cool-season grasses. Askew et al. (2003) reported that both isoxaflutole and mesotrione (Tenacity ${ }^{\mathrm{TM}}$ 4SC; Syngenta Crop Protection, Greensboro, NC) could provide selective bentgrass removal in kentucky bluegrass (Poa pratensis) and perennial ryegrass (Lolium perenne). Mesotrione is a systemic herbicide and works by inhibiting $p$-hydroxyphenylpyruvate dioxygenase (HPPD),

${ }^{1}$ School of Applied Chemistry and Biotechnology, Shenzhen Polytechnic, Guangdong 518055, China

${ }^{2}$ Department of Plant Sciences, North Dakota State University, Fargo, ND 58108

${ }^{3}$ Institute of Genetics and Developmental Biology, Chinese Academy of Sciences, Beijing 100101, China

${ }^{4}$ Corresponding author. E-mail: deying.li@ndsu.edu. an enzyme essential for the biosynthesis of carotenoids. Without carotenoids, excessive light energy destroys chlorophyll and causes new growth to appear white before necrosis and death (Giese et al., 2005). Selective removal of creeping bentgrass from kentucky bluegrass was achieved by using mesotrione at three sequential applications of $420 \mathrm{~g} \cdot \mathrm{ha}^{-1}$ in a study by Branham et al. (2005). Beam et al. (2006) reported $58 \%$ to $100 \%$ creeping bentgrass control by repeated treatments of the grass with mesotrione at a minimum rate of $280 \mathrm{~g} \cdot \mathrm{ha}^{-1}$. Volunteer creeping bentgrass often recovers from the injury caused by the herbicide, and thus, more applications are needed for eradication (Branham et al., 2005).

Mixing a herbicide with an adjuvant is a common practice to improve herbicide's efficacy (Nalewaja et al., 1995). Giese et al. (2005) reported that mesotrione (140 to $420 \mathrm{~g} \cdot \mathrm{ha}^{-1}$ ) provided better control of creeping bentgrass with NIS than with methylated seed oil. Fertilizer salts, such as
UAN and ammonium sulfate, often are added to spray solutions with NIS to help increase the activity of foliar-applied herbicides (Pearson et al., 2008). The exact mechanism of action of ammonium salts is not clear, although increased absorption into plants has been reported (Bruce et al., 1993; Dodds et al., 2007; Fandrich et al., 2001). Li and Howatt (2006) reported that creeping bentgrass control was improved when UAN was added to mesotrione at a rate of $17.5 \mathrm{~g} \cdot \mathrm{ha}^{-1}$ plus NIS in a greenhouse experiment.

Cultural practices have been recommended alone or in combination with chemical methods for weed control (Calhoun et al., 2005). The efficacy of chemical weed control in turfgrass can be improved by using relatively taller mowing heights, which keep the turfgrass healthier in many cases (Dernoeden, 2001; Jagschitz and Ebdon, 1981). At a mowing height that is suitable for perennial ryegrass, little of the creeping bentgrass will be removed. Constant low mowing will remove the dead tissues of the creeping bentgrass and will increase the exposure of leaves in the lower canopy to sunlight. This may increase the efficacy of mesotrione. McCurdy et al. (2009) reported that mesotrione control of large crabgrass (Digitaria sanguinalis) was unaffected by various levels of temperature and irradiance. Limited information is available on the effects of light on creeping bentgrass control using mesotrione.

We hypothesize that increased exposure to sunlight by removing the dead tissues may result in more injury to the lower leaves by mesotrione. The level of phytotoxicity could then be detected by monitoring the integrity and activity of photosynthesis systems that are affected by the mode of action of mesotrione. Chlorophyll content and quantum yield of photosynthesis system II (PSII)-mediated electron transport are often measured for this purpose in physiological studies

\begin{tabular}{llll}
\hline $\begin{array}{l}\text { Units } \\
\begin{array}{l}\text { To convert U.S. to SI, } \\
\text { multiply by }\end{array}\end{array}$ & U.S. units & SI units & $\begin{array}{l}\text { To convert SI to U.S., } \\
\text { multiply by }\end{array}$ \\
\hline 9.3540 & gal/acre & $\mathrm{L} \cdot \mathrm{ha}^{-1}$ & 0.1069 \\
2.54 & inch $(\mathrm{es})$ & $\mathrm{cm}$ & 0.3937 \\
48.8243 & $\mathrm{lb} / 1000 \mathrm{ft}^{2}$ & $\mathrm{~kg} \cdot \mathrm{ha}^{-1}$ & 0.0205 \\
70.0532 & $\mathrm{oz} / \mathrm{acre}$ & $\mathrm{g} \cdot \mathrm{ha}^{-1}$ & 0.0143 \\
1 & $\mathrm{ppm}$ & $\mathrm{mg} \cdot \mathrm{kg}^{-1}$ & 1 \\
6.8948 & $\mathrm{psi}$ & $\mathrm{kPa}$ & 0.1450
\end{tabular}


(Ounis et al., 2001). The objective of this study was to evaluate the effect on selective creeping bentgrass control from adding UAN to NIS plus mesotrione and from removing dead tissues of creeping bentgrass before the application of herbicides.

\section{Materials and methods}

The experiment was conducted in field plots at the Agricultural Experiment Station, Fargo, ND, in 2007 and was repeated in 2008. The soil was a Fargo-Ryan silty clay [(fine, montmorillonitic, frigid Vertic Haplaquall)(fine, montmorillonitic, Typic Natraquoll)], with $2 \%$ sand, $46 \%$ silt, $52 \%$ clay, $4.6 \%$ organic matter, and $\mathrm{pH} 7.8$. The soil phosphorous $(\mathrm{P})$ and potassium $(\mathrm{K})$ content was 68 and 320 $\mathrm{mg} \cdot \mathrm{kg}^{-1}$, respectively. The turf stand was a 'BrightStar' perennial ryegrass established in Sept. 2002 and overseeded with 'Penncross' creeping bentgrass in May 2005. The grass was mowed weekly at 2.19 inches height. Nitrogen $(\mathrm{N})$ was applied at an annual rate of $2 \mathrm{lb} / 1000 \mathrm{ft}^{2}$ from polymer-coated sulfur-coated urea (43N-0P-0K, NS-54; The Andersons, Maumee, $\mathrm{OH}$ ) in two equal applications in May and September of both years. Potassium was applied at an annual rate of $3.5 \mathrm{lb} / 1000 \mathrm{ft}^{2}$ from potassium sulfate $(0 \mathrm{~N}-0 \mathrm{P}-41.5 \mathrm{~K})$ (The Andersons) in two equal applications in May and September of both years. Irrigation was provided to prevent drought stress on perennial ryegrass.

The experiment was a balanced split-plot design, with the main plot arranged in a randomized complete block with three replicates. Raking was the whole-plot treatment and herbicide was the sub-plot treatment. Herbicide treatments included application of mesotrione at 56 and $70 \mathrm{~g} \cdot \mathrm{ha}^{-1}$ singly and sequentially on a 2 -week interval with $0.25 \%(\mathrm{v} / \mathrm{v})$ NIS (R-11; Wilbur-Elllis, Fresno, CA) or $0.25 \%$ $(\mathrm{v} / \mathrm{v})$ NIS plus $2.5 \%(\mathrm{v} / \mathrm{v})$ UAN solution that contained 28\% N (Nortrace, Greeley, CO) (Table 1). The first treatment in 2007 was initiated on 17 Aug., and the first treatment in 2008 was initiated on 24 July. The single treatment was applied at the same time as the first application of the split treatments. The herbicide was applied with a backpack sprayer pressurized with carbon dioxide at $250 \mathrm{kPa}$ and equipped with flat-fan nozzles at 19 inches spacing held at about 18 inches above the surface of the soil (8002VS; TeeJet Spray Systems, Springfield, IL) to deliver a spray volume of 10 $\mathrm{gal} / \mathrm{acre}$.

Half of the plots were power raked at $3 \mathrm{~cm}$ height before the first herbicide treatment and weekly thereafter (Bluebird International, Charlotte, $\mathrm{NC}$ ). The clippings were manually collected and removed afterward using a spring rake. Creeping bentgrass control was visually evaluated weekly after the first treatment based on a 0 to 100 scale, where $0=$ no effect, 1 to $30=$ slight, 31 to $60=$ moderate (rating above 30 considered unacceptable injury), 61 to $99=$ severe injury , and $100=$ complete death (Camper, 1986). The quantum yield of PSII-mediated electron transport, which was a ratio of variable chlorophyll fluorescence to maximal

Table 1. Treatment list for creeping bentgrass control with mesotrione at different rates, timings, and adjuvants.

\begin{tabular}{cccc}
\hline $\begin{array}{c}\text { Mesotrione } \\
\left(\mathrm{g} \cdot \mathrm{ha}^{-1}\right)^{\mathrm{z}}\end{array}$ & $\begin{array}{c}\text { Non-ionic } \\
\text { surfactant }(\%)^{\mathrm{y}}\end{array}$ & $\begin{array}{c}\text { Urea ammonium } \\
\text { nitrate }(\%)^{\mathrm{x}}\end{array}$ & $\begin{array}{c}\text { Applications } \\
(\text { no. })\end{array}$ \\
\hline 0 & 0.25 & 0 & 3 \\
0 & 0.25 & 2.5 & 3 \\
56 & 0.25 & 0 & 3 \\
56 & 0.25 & 2.5 & 3 \\
70 & 0.25 & 0 & 3 \\
70 & 0.25 & 2.5 & 3 \\
168 & 0.25 & 0 & 1 \\
168 & 0.25 & 2.5 & 1 \\
210 & 0.25 & 0 & 1 \\
210 & 0.25 & 2.5 & 1 \\
\hline
\end{tabular}

Experiment was conducted in field plots at North Dakota Agricultural Experiment Station, Fargo, in 2007 and 2008.

${ }^{2} \mathrm{lg} \cdot \mathrm{ha}^{-1}=0.0143 \mathrm{oz} /$ acre.

${ }^{y}$ R-11 (Wilbur-Ellis, Fresno, CA).

Solution containing $28 \%$ nitrogen (Nortrace, Greeley, CO).

chlorophyll fluorescence ( $\mathrm{Fv} / \mathrm{Fm})$, was measured using a fluorometer (PAM2000; Heinz Walz, Effeltrich, Germany) at constant light illumination without dark adaptation. Five leaf blades were affixed to the surface of a cellophane tape with the adaxial side up for the quantum yield measurement, and three samples were taken in each sub-plot. The measurements were conducted up to 6 weeks after treatment (WAT). Evaluation of creeping bentgrass survival was also conducted in the following spring, 29 May 2008 and 14 May 2009.

The MIXED procedure from statistical analysis software (SAS, version 9.1.3; SAS Institute, Cary, NC) was used to identify the main effects and interaction effects. Replication and twoway interaction between raking and replication were treated as random factors. Fisher's protected least significant difference was used to compare treatment means. Data were presented separately for the 2 years because of different variability.

\section{Results and discussion}

Removing clippings and dead tissues by raking before the application of herbicide resulted in better creeping bentgrass control 3 to 6 WAT in 2007, but only at 3 and 4 WAT in 2008 (Table 2). The raking effects on creeping bentgrass control appeared not only during the year of application of herbicide but also in the following springs for both years (Table 3 ). It is speculated that the differences between the 2 years might be attributed to the lower average solar radiation of $16.1 \mathrm{MJ} \cdot \mathrm{m}^{-2}$ in 2007 vs. $22.5 \mathrm{MJ} \cdot \mathrm{m}^{-2}$ in 2008 during the months of study. Removal of clippings of dead creeping bentgrass in 2007 probably allowed the sunlight to reach the lower canopy. In the 2008 study, however, higher light possibly allowed the penetration of enough light regardless of clipping removal treatments. Power raking also could have improved the control by injuring creeping bentgrass that was already weak from applications of mesotrione. Other environmental conditions might have also contributed to the differences. Johnson and Young (2002) reported that mesotrione was more effective at low temperature and high relative humidity, with foliar application on large crabgrass. Increased relative humidity also was reported to increase smooth crabgrass (Digitaria 
ischaemum) and tall fescue (Schedonorus phoenix) control by mesotrione application (Goddard et al., 2010). Therefore, more research is needed to explain the different raking effects from 2 years.

Sequential applications of 70 $\mathrm{g} \cdot \mathrm{ha}^{-1}$ in a 2 -week interval with UAN added to NIS provided the highest observed creeping bentgrass control of 93\% in 2007 and $97 \%$ in 2008 (Table 4). In both years, adding UAN to NIS improved the efficacy of mesotrione when applied at either low or high rates.
Although other reports showed that three sequential applications of mesotrione can achieve $97 \%$ to $99 \%$ control in 8 weeks after initiation of the treatment (Jones and Christians, 2007), this study showed that, without raking or adding UAN to the spray solution, only $78 \%$ to $82 \%$ control was achieved. Compared with other treatments, only the three sequential treatments of $70 \mathrm{~g} \cdot \mathrm{ha}^{-1}$ applied at 2 -week interval with both UAN and NIS provided the complete control of creeping bentgrass in the spring evaluation 1 year following the field study (Table 4).

The effect of UAN and clipping removal on the efficacy of mesotrione also was shown in the quantum yield of PSII-mediated electron transport (Table 5). The control at 6 WAT was negatively correlated to the quantum yield in both $2007\left(r=-0.69^{* *}\right)$ and $2008\left(r=-0.78^{* *}\right)$. Decreased quantum yield of PSII often is related to physiological stress (Ounis et al., 2001). This study showed that the potential of using quantum yield of PSII as an

Table 2. Analysis of variance of creeping bentgrass control as affected by the herbicide and removal of dead tissues by raking.

\begin{tabular}{|c|c|c|c|c|c|c|c|c|c|c|c|c|c|c|c|}
\hline \multirow{3}{*}{$\begin{array}{l}\text { Source of } \\
\text { variance }\end{array}$} & \multirow[b]{3}{*}{ df } & \multicolumn{14}{|c|}{ Creeping bentgrass control (\%) } \\
\hline & & \multicolumn{2}{|c|}{ I WAT } & \multicolumn{2}{|c|}{2 WAT } & \multicolumn{2}{|c|}{3 WAT } & \multicolumn{2}{|c|}{4 WAT } & \multicolumn{2}{|c|}{5 WAT } & \multicolumn{2}{|c|}{$6 \mathrm{WAT}$} & \multicolumn{2}{|c|}{ Follow spring } \\
\hline & & 2007 & 2008 & 2007 & 2008 & 2007 & 2008 & 2007 & 2008 & 2007 & 2008 & 2007 & 2008 & 2008 & 2009 \\
\hline Herbicide & 7 & ** & ** & ** & ** & ** & ** & ** & ** & ** & ** & ** & ** & ** & ** \\
\hline Rake $\times$ Herbicide & 7 & NS & NS & NS & NS & NS & NS & NS & NS & NS & NS & NS & NS & NS & NS \\
\hline
\end{tabular}

The herbicide mesotrione was applied at annual rates of 168 and $210 \mathrm{~g} \cdot \mathrm{ha}^{-1}(2.4$ and $3.0 \mathrm{oz} / \mathrm{acre}$ ) with one or three split applications at 2 -week interval and with $0.25 \%$ (v/v) non-ionic surfactant [NIS (R-11; Wilbur-Ellis, Fresno, CA)] or $0.25 \%(\mathrm{v} / \mathrm{v}$ ) NIS plus $2.5 \%$ urea ammonium nitrate solution (v/v) that contains $28 \%$ nitrogen (Nortrace, Greeley, CO). Experiment was conducted in the field plots at North Dakota Agricultural Experiment Station, Fargo, in 2007 and 2008.

WAT $=$ weeks after treatment.

Ns, * ${ }^{* *}$ Nonsignificant or significant at $P \leq 0.05$ or 0.01 , respectively.

Table 3. Effects of dead tissue removal by raking on creeping bentgrass control, using mesotrione with values averaged across different rates, timings, and adjuvants.

\begin{tabular}{|c|c|c|c|c|c|c|c|c|c|c|c|c|c|c|}
\hline \multirow[b]{3}{*}{ Treatments } & \multicolumn{14}{|c|}{ Creeping bentgrass control (\%) } \\
\hline & \multicolumn{2}{|c|}{ I WAT } & \multicolumn{2}{|c|}{2 WAT } & \multicolumn{2}{|c|}{3 WAT } & \multicolumn{2}{|c|}{4 WAT } & \multicolumn{2}{|c|}{5 WAT } & \multicolumn{2}{|c|}{6 WAT } & \multicolumn{2}{|c|}{ Spring } \\
\hline & 2007 & 2008 & 2007 & 2008 & 2007 & 2008 & 2007 & 2008 & 2007 & 2008 & 2007 & 2008 & 2008 & 2009 \\
\hline Non-raked & $33 \mathrm{a}$ & 39 a & $52 \mathrm{a}$ & $52 \mathrm{~b}$ & $52 \mathrm{~b}$ & $61 \mathrm{~b}$ & $56 \mathrm{~b}$ & $70 \mathrm{~b}$ & $60 \mathrm{~b}$ & $71 \mathrm{a}$ & $41 \mathrm{~b}$ & $57 \mathrm{a}$ & $60 \mathrm{~b}$ & $61 \mathrm{~b}$ \\
\hline
\end{tabular}

Mesotrione was applied at annual rates of 168 and $210 \mathrm{~g} \cdot \mathrm{ha} \mathrm{H}^{-1}(2.4$ and $3.0 \mathrm{oz} / \mathrm{acre}$ ) with one or three split applications at 2 -week interval, and with $0.25 \%$ (v/v) non-ionic surfactant [NIS (R-11; Wilbur-Ellis)] or $0.25 \%(\mathrm{v} / \mathrm{v})$ NIS plus $2.5 \%$ urea ammonium nitrate solution (v/v) that contains $28 \%$ nitrogen (Nortrace). Experiment was conducted in the field plots at North Dakota Agricultural Experiment Station, Fargo, in 2007 and 2008.

WAT $=$ weeks after treatment.

${ }^{2}$ Values followed by a same letter within a column are not significantly different at $P=0.05$ separated by Fisher's protected least significant difference.

Table 4. Creeping bentgrass control with mesotrione at different rates, timings, and adjuvants, with values averaged across rake treatments for dead tissue removal.

\begin{tabular}{|c|c|c|c|c|c|c|c|c|c|c|c|c|c|c|c|}
\hline \multirow[b]{3}{*}{ Mesotrione $^{\mathrm{z}}$} & \multirow[b]{3}{*}{ Adjuvant $^{\mathrm{y}}$} & \multicolumn{14}{|c|}{ Creeping bentgrass control (\%) } \\
\hline & & \multicolumn{2}{|c|}{ I WAT } & \multicolumn{2}{|c|}{2 WAT } & \multicolumn{2}{|c|}{3 WAT } & \multicolumn{2}{|c|}{4 WAT } & \multicolumn{2}{|c|}{5 WAT } & \multicolumn{2}{|c|}{$6 \mathrm{WAT}$} & \multicolumn{2}{|c|}{ Spring } \\
\hline & & 2007 & 2008 & 2007 & 2008 & 2007 & 2008 & 2007 & 2008 & 2007 & 2008 & 2007 & 2008 & 2008 & 2009 \\
\hline L3 & NIS - & $32 \mathrm{bc}$ & $37 \mathrm{bc}$ & $39 \mathrm{~cd}$ & $35 \mathrm{e}$ & $44 c$ & $46 \mathrm{c}$ & $58 \mathrm{c}$ & $63 c$ & $67 c$ & $72 \mathrm{c}$ & $59 \mathrm{c}$ & $64 c$ & $62 \mathrm{~b}$ & $70 \mathrm{~b}$ \\
\hline $\mathrm{H} 3$ & NIS & $27 \mathrm{~cd}$ & $32 \mathrm{c}$ & $40 \mathrm{~cd}$ & $47 \mathrm{~d}$ & $60 \mathrm{~b}$ & $65 \mathrm{~b}$ & $60 \mathrm{c}$ & $65 c$ & $71 \mathrm{bc}$ & $77 \mathrm{bc}$ & $78 \mathrm{~b}$ & $82 \mathrm{~b}$ & $70 \mathrm{~b}$ & $78 \mathrm{~b}$ \\
\hline $\mathrm{H} 3$ & $\mathrm{NIS}+\mathrm{UAN}$ & $32 \mathrm{bc}$ & $37 \mathrm{bc}$ & $44 \mathrm{c}$ & $49 \mathrm{dc}$ & $71 \mathrm{a}$ & $76 \mathrm{a}$ & $71 \mathrm{~b}$ & $76 \mathrm{~b}$ & $86 a$ & $91 \mathrm{a}$ & $93 \mathrm{a}$ & $97 \mathrm{a}$ & $97 \mathrm{a}$ & $98 \mathrm{a}$ \\
\hline $\mathrm{Hl}$ & NIS & $39 \mathrm{ab}$ & $47 \mathrm{a}$ & $72 \mathrm{a}$ & $76 a$ & $75 \mathrm{a}$ & $81 \mathrm{a}$ & $81 \mathrm{a}$ & $86 a$ & $72 \mathrm{bc}$ & $77 \mathrm{bc}$ & $34 \mathrm{e}$ & $50 \mathrm{~d}$ & $30 \mathrm{~d}$ & $44 \mathrm{c}$ \\
\hline $\mathrm{Hl}$ & $\mathrm{NIS}+\mathrm{UAN}$ & $43 \mathrm{a}$ & $48 \mathrm{a}$ & $70 \mathrm{a}$ & $75 \mathrm{a}$ & $77 \mathrm{a}$ & $83 \mathrm{a}$ & $81 \mathrm{a}$ & $86 a$ & $79 \mathrm{ab}$ & $81 \mathrm{~b}$ & $35 \mathrm{de}$ & $51 \mathrm{~d}$ & $32 \mathrm{~d}$ & $40 \mathrm{c}$ \\
\hline
\end{tabular}

Experiment was conducted in the field plots at North Dakota Agricultural Experiment Station, Fargo, in 2007 and 2008.

WAT $=$ weeks after treatment.

${ }^{\mathrm{z}} \mathrm{L} 3$ and $\mathrm{H3}=$ mesotrione applied at 56 and $70 \mathrm{~g} \cdot \mathrm{ha}^{-1}$, respectively, three times in 2 -week interval; $\mathrm{Ll}$ and $\mathrm{Hl}=$ mesotrione applied once at 168 and $210 \mathrm{~g} \cdot \mathrm{ha}{ }^{-1}$, respectively; 1 $\mathrm{g} \cdot \mathrm{ha} \mathrm{a}^{-1}=0.0143 \mathrm{oz} / \mathrm{acre}$.

${ }^{y} \mathrm{NIS}=$ non-ionic surfactant $(\mathrm{R}-11$; Wilbur-Ellis, Fresno, CA $)$ at $0.25 \%(\mathrm{v} / \mathrm{v}), \mathrm{UAN}=$ urea and ammonium nitrate at $2.5 \%$ solution $(\mathrm{v} / \mathrm{v})$ that contains $28 \%$ nitrogen $($ Nortrace, Greeley, CO).

${ }^{x}$ Numbers in a column followed by same letters indicate no significant difference at $P=0.05$ separated by Fisher's protected least significant difference. 


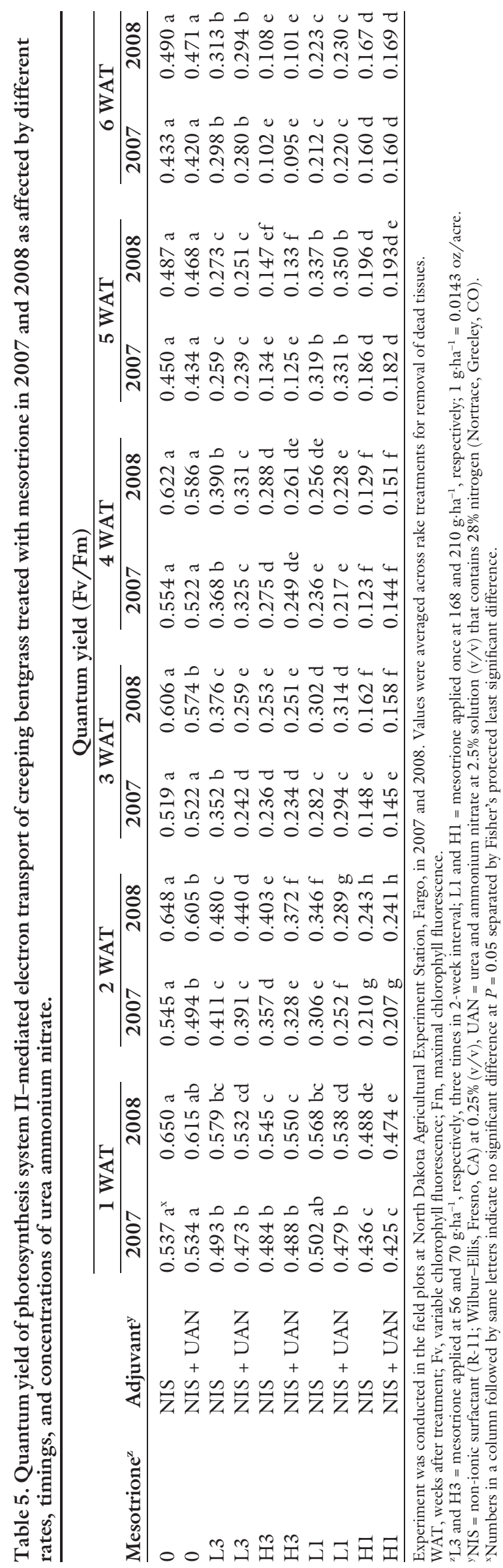

objective parameter of phytotoxicity caused by HPPD herbicides is worth further investigation.

In conclusion, mesotrione at or below an annual total rate of $210 \mathrm{~g} \cdot \mathrm{ha}^{-1}$ applied with NIS, whether in one application or in three sequential applications on 2-week interval, provided only moderate creeping bentgrass control under the climate and soil conditions at North Dakota. Removal of dead clippings and adding UAN to NIS plus mesotrione provided satisfactory creeping bentgrass control with three sequential treatments at the rate of $70 \mathrm{~g} \cdot \mathrm{ha}^{-1}$. The exact mechanism of the improvement requires further study. Our research shows that, because of the growth habit of creeping bentgrass, very little volunteer creeping bentgrass will be removed when an application of mesotrione is made to the lawn height cool-season grasses. Turf managers may need to remove dead turf tissues by raking before sequential mesotrione treatments to improve efficacy.

\section{Literature cited}

Adams, W.A. 1981. Effects of nitrogen fertilization and cutting height on the shoot growth, nutrient removal and turfgrass composition of an initially perennial ryegrass dominant sports turf. Intl. Turfgrass Soc. Res. J. 4:343-350.

Askew, S.D., J.B. Beam, and W.L. Barker. 2003. Isoxaflutole and mesotrione for weed management in cool-season turfgrass. Proc. Annu. Mtg. Northeast Weed Sci. Soc. 57:111.

Beam, J.B., W.L. Barker, and S.D. Askew. 2006. Selective creeping bentgrass (Agrostis stolonifera) control in cool-season turfgrass. Weed Technol. 20:340-344.

Bhowmik, P.C. and J.A. Drohen. 2001. Differential response of cool-season turfgrass species to isoxaflutole. Intl. Turfgrass Soc. Res. J. 9:995-1000.

Branham, B.E., W. Sharp, E.A. Kohler, T.W. Fermanian, and T.B. Voigt. 2005. Selective control of creeping bentgrass (Agrostis stolonifera L.) in kentucky bluegrass (Poa pratensis L.) turf. Intl. Turfgrass Soc. Res. J. 10:1164-1169.

Bruce, J.A., D. Penner, and J.J. Kells. 1993. Absorption and activity of nicosulfuron and primisulfuron in quackgrass (Elytrigia repens) as affected by adjuvants. Weed Sci. 41:218-224.

Calhoun, R.N., G.J. Rinehart, A.A. Hathaway, and D.D. Buhler. 2005. Maximizing cultural practices to minimize 
weed pressure and extend herbicide treatment interval in a cool-season turfgrass mixture. Intl. Turfgrass Soc. Res. J. 10: 1184-1188.

Camper, N.D. 1986. Research methods in weed science. 3rd ed. Southern Weed Sci. Soc., Champaign, I.L.

Dernoeden, P.H. 2001. Reduced herbicide rates for smooth crabgrass control in the mid-Atlantic region. Intl. Turfgrass Soc. Res. J. 9:1005-1008.

Dodds, D.M., D.B. Reynolds, J.H. Massey, M.C. Smith, and C.H. Koger. 2007. Effect of adjuvant and urea ammonium nitrate on bispyribac efficacy, absorption, and translocation in barnyardgrass (Echinochloa crus-galli). II. Absorption and translocation. Weed Sci. 55:406-411.

Fandrich, L., S.K. McDonald, S.J. Nissen, P. Westra, and H.J. Santel. 2001. Absorption and fate of BAY MKH 6561 in jointed goatgrass and downy brome. Weed Sci. 49:717-722.

Giese, M.S., R.J. Keese, N.E. Christians, and R.E. Gaussoin. 2005. Mesotrione: A potential selective post-emergence herbi- cide for turf grass, p. 100-101. In: D Thorogood (ed.). ITS Annexe-Technical Papers Volume 10. Intl. Turfgrass Soc., Fort Lauderdale, FL.

Goddard, M.J.R., J.B. Willis, and S.D. Askew. 2010. Application placement and relative humidity affects smooth crabgrass and tall fescue response to mesotrione. Weed Sci. 58:67-72.

Jagschitz, J.A. and J.S. Ebdon. 1981. Influence of mowing, fertilizer and herbicide on crabgrass infestation in red fescue turf. Intl. Turfgrass Soc. Res. J. 4:699704.

Johnson, B.C. and B.G. Young. 2002. Influence of temperature and relative humidity on the foliar activity of mesotrone. Weed Sci. 50:157-161.

Jones, M.A. and N.E. Christians. 2007. Mesotrione controls creeping bentgrass (Agrostis stolonifera) in kentucky bluegrass. Weed Technol. 21:402405 .

Li, D. and K. Howatt. 2006. Postemergence control of creeping bentgrass in kentucky bluegrass and perennial ryegrass.
Amer. Soc. Agron.-Crop Sci. Soc. Amer.-Soil Sci. Soc. Amer. Intl. Annu. Mtg., Indianapolis, 12-16 Nov. 2006.

McCurdy, J.D., J.S. McElroy, D.A. Kopsell, and C.E. Sams. 2009. Mesotrione control and pigment concentration of large crabgrass (Digitaria sanguinalis) under varying environmental conditions. Pest Mgt. Sci. 65:640-644.

Nalewaja, J.D., T. Praczyk, and R. Matysiak. 1995. Surfactants and oil adjuvants with nicosulfuron. Weed Technol. 9:689-695.

Ounis, A., S. Wvain, J. Flexas, S. Tosti, and I. Moya. 2001. Adaptation of a PAMfluorometer for remote sensing of chlorophyll fluorescence. Photosyn. Res. 68: 113-120.

Pearson, B.A., R.C. Scott, and V.F. Carey, III. 2008. Urea ammonium nitrate effects on bispyribac and penoxsulam efficacy. Weed Technol. 22:597-601.

Turgeon, A.J. 1981. Turfgrass pest management. Intl. Turfgrass Soc. Res. J. 4: $351-368$. 